\section{Evidência de reação cruzada no sorodiagnóstico da infecção pelo vírus da imunodeficiência humana (HIV-1) determinada pela presença de anticorpos anti $P$. falciparum}

Este estudo foi realizado com o objetivo de avaliar a existência de reação cruzada sorológica entre anticorpos anti- $P$. falciparum e antígenos do vírus da imunodeficiência humana (HIV-1), tema que mostra resultados contraditórios na literatura médica. Para tal, estudamos 184 amostras de soro coletadas de pessoas residentes em Peixoto de Azevedo, cidade localizada ao norte do Estado de Mato Grosso, área endêmica de malária. Utilizamos três testes de ensaio imunoenzimático (EIA), de 1 ${ }^{\mathrm{a}}$, $2^{\text {a }}$ e $3^{\text {a }}$ geração, para a pesquisa de anticorpos anti-HIV na triagem das amostras coletadas. Às amostras positivas e inconclusivas foi aplicado o teste Western Blot (WB). As amostras com resultado positivo e indeterminado ao WB foram incubadas com extrato antigênico de Plasmodium falciparum cultivado em hemáceas, para absorção dos anticorpos anti- $P$. falciparum. O teste WB foi repetido após o experimento de absorção. Avaliamos a prevalência de anticorpos anti-P. falciparum nesta população, utilizando o teste ELISA. Das 184 amostras testadas, 21 $(11 \%)$ foram anti-HIV reagentes ao teste EIA; destas, 1 foi positiva, 6 negativas e 14 (67\%) indeterminadas ao WB (WBI). As 14 amostras WBI foram positivas para anticorpos anti- $P$. falciparum pelo ELISA. Nove amostras WBI foram absorvidas com extrato antigênico de $P$. falciparum havendo negativação das bandas ao WB para malária, confirmando que tais anticorpos foram absorvidos. Estas amostras foram retestadas com WB anti-HIV-1, sendo que 7 (78\%) das 9 tornaram-se negativas. A única amostra anti-HIV positiva ao WB deste estudo e mais uma amostra positiva obtida de um paciente com diagnóstico de AIDS de São Paulo, utilizadas como controle positivo, permaneceram positivas após a absorção com o extrato antigênico de $P$. falciparum. Estes resultados mostram que a reatividade anti-HIV

\section{Evidence of cross reactivity in human immunodeficiency virus (HIV-1) serodiagnosis determined by the presence of P. falciparum antibodies}

This study was conducted to examine the serologic cross reactivity between anti$P$. falciparum antibodies and antigens of the human immunodeficiency virus (HIV-1), where previously published studies have shown conflicting results. Towards this end we studied sera samples of 184 subjects from Peixoto de Azevedo, a city in northern Mato Grosso, endemic for malaria. We used three different (first, second and third generation) enzyme immuno-assay tests (EIA) to screen the study sera for HIV antibodies. Reactive tests (positive and inconclusive) were then tested by Western Blot (WB). Aliquots from samples which tested WB positive and indeterminate were then incubated with $P$. falciparum antigen, extracted from parasite cultures, to absorb anti-P. falciparum antibodies. WB tests were then repeated following the absorption procedure. We used malaria ELISA tests to examine the prevalence of anti- $P$. falciparum antibodies in this population. Of the 184 subjects tested, 21 (11\%) were reactive to the screening EIA HIV tests: of which one was positive, six negative and 14 $(67 \%)$ indeterminate by WB. All 14 of these indeterminate WB (IWB) tested positive for anti- $P$. falciparum antibodies by malaria ELISA test. Aliquots from nine of the 14 IWB subjects were incubated with extracted $P$. faciparum antigen with subsequent negativization of malaria Western Blot bands, confirming malaria antibody absorption. The retesting of these sera, following the absorption procedure, showed seven of the nine with a reversion from IWB status (HIV) to negative. The single positive WB sera as well as one positive control, consisting of sera from serologically and clinically confirmed AIDS case from Sao Paulo (nonendemic for malaria), remained positive by WB test following the absorption procedure. These results imply that the anti-HIV reactivity of the

Recebido para publicação em 06/04/98. 
destes soros foi determinada por anticorpos anti- $P$.falciparum que apresentam reatividade cruzada a antígenos do HIV-1. sera was caused by anti- $P$. falciparum antibodies which are cross reactive to antigens used in the HIV-1 WB test.

\section{Marise Oliveira Fonseca}

Dissertação apresentada à Faculdade de Medicina da

Universidade de São Paulo para obtenção

do Título de Mestre.

São Paulo, SP, Brasil, 1996. 